\title{
Economic analysis and risk assessment in the process of implementing innovative products on the example of impregnated grinding wheels
}

Emilia GIERSZEWSKA, Krzysztof NADOLNY

DOI: 10.30464/jmee.2019.3.4.289

Cite this article as:

Gierszewska E., Nadolny K. Economic analysis and risk assessment in the process of implementing innovative products on the example of impregnated grinding wheels. Journal of Mechanical and Energy Engineering, Vol. 3(43), No. 4, 2019, pp. 289-294.

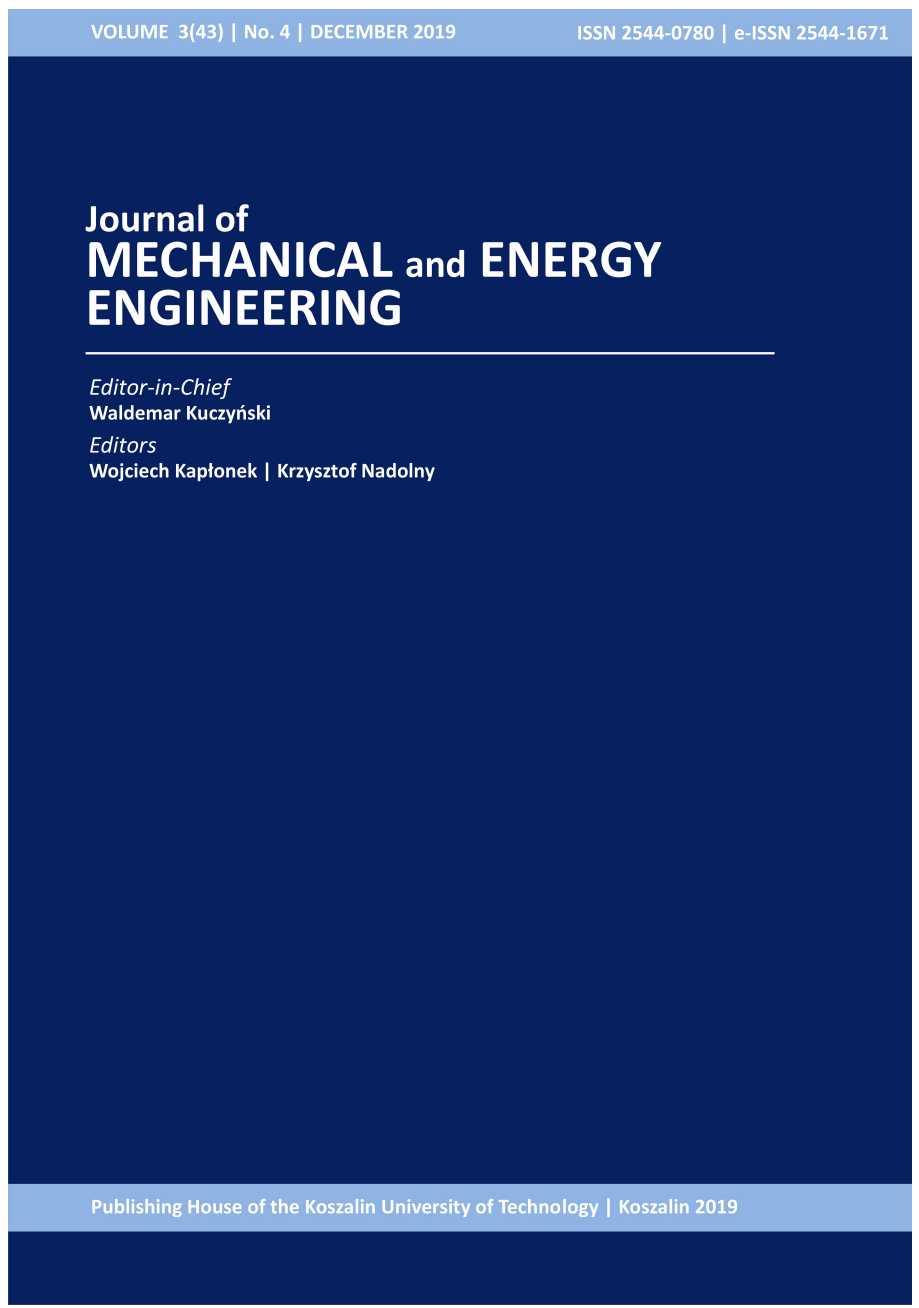

Journal of Mechanical and Energy Engineering

Website: jmee.tu.koszalin.pl

ISSN (Print): 2544-0780

ISSN (Online): 2544-1671

Volume: $3(43)$

Number: 4

Year: 2019

Pages: 289-294

Article Info:

Received 04 December 2019

Accepted 20 December 2019

\section{Open Access}

This article is distributed under the terms of the Creative Commons Attribution 4.0 (CC BY 4.0) International License (http://creativecommons.org/licenses/by/4.0/), which permits unrestricted use, distribution, and reproduction in any medium, provided you give appropriate credit to the original author(s) and the source, provide a link to the Creative Commons license, and indicate if changes were made. 


\title{
ECONOMIC ANALYSIS AND RISK ASSESSMENT IN THE PROCESS OF IMPLEMENTING INNOVATIVE PRODUCTS ON THE EXAMPLE OF IMPREGNATED GRINDING WHEELS
}

\author{
Emilia GIERSZEWSKA $^{1 *}$, Krzysztof NADOLNY ${ }^{2}$ \\ 1* Faculty of Mechanical Engineering, Department of Production Engineering, Koszalin University of \\ Technology, Raclawicka 15-17, 75-620 Koszalin, Poland, e-mail: emilia.gierszewska@wp.pl \\ ${ }^{2}$ Faculty of Mechanical Engineering, Department of Production Engineering, Koszalin University of \\ Technology, Poland
}

(Received 04 December 2019, Accepted 20 December 2019)

\begin{abstract}
This article presents issues related to the search for new products. The process of innovation implementation in a production company is characterized. Issues related to the process of innovation implementation are presented, as well as processes closely related to it. There are presented the analyses which are necessary to carry out, before starting the process of innovation implementation in a company. The process of economic analyses and risk assessment of FMEA implementation was discussed. The analyses presented refer to a specific example which is the implementation of innovative impregnated wheels in the company Andre Abrasive Articles.
\end{abstract}

Keywords: innovation, implementation, economic analysis, implementation risk analysis, impregnated grinding wheels

\section{INTRODUCTION}

The main purpose of each company's activity is to make a profit. The consumer is the key player in making a company profitable. The constant development of the world makes consumers look for new solutions, so their requirements are constantly changing. Enterprises, in order to make a profit, and thus meet the needs of consumers, must constantly seek new solutions that meet consumer requirements. The key to this is the innovative activity of the company. Unfortunately, as presented in the Innovation Union Scoreboard report of 2016, the innovation index in Poland is 0.29175 , while the average European Union is 0.52149 and therefore it is a country of moderate innovation [13].

The Global Creativity Index, which presents the creativity of individual countries, indicates that Poland is ranked 21 st in the hundred of the 28 European Union countries [4].

Both the search and implementation of innovations is a time-consuming and often very costly process. Therefore, while working on innovations, it is also necessary to carry out economic analyses and risk analyses of FMEA (Failure Mode and Effects Analysis) implementation. Conducting implementation risk analyses and economic analyses allows, to a certain extent, to predict the effects associated with the process of introducing a new solution and its profitability.

\section{INNOVATION IN THE ENTERPRISE}

The right word to use to describe the modern economy is globalisation. On the world market, goods with similar characteristics, properties and intended use are mass produced. The prevailing competitiveness on the market contributes to the fact that companies benefit only when they constantly introduce new products into circulation [10].

The key factor of innovation development is competitiveness. In order to maintain their position on the market, companies must constantly search for new solutions and strive to implement them in order to meet the new needs of buyers [11]. 


\subsection{Concept of innovation}

The concept of innovation was first defined in the 20th century. This was done by the Austrian economist Joseph Schumpeter in his theory of creative destruction developed in 1934. In this work Schumpeter pointed out that innovation is the basis of development, which is understood as a process of displacement of old technologies by new ones, which are more effective [5].

Schumpeter, in his work Theory of Economic Development, defined the term innovation as the following events:

- the introduction into circulation of a new product, not yet existing on the market, or a new type of product,

- implementation of a new production method not yet tested in a given industry,

- launching a new market, one in which a particular type of domestic industry has not yet been active, regardless of whether this market existed before or not,

- gain a new source of raw materials or semifinished products, regardless of whether this source existed previously or was just created,

- implementation of a new industry organisation, The concept of innovation presented by Schumpeter is constantly quoted in publications on innovation management. This is the classic definition of innovation

\subsection{Development of the concept of innovation}

At the beginning of the 20th century, innovation was mainly understood as a new technical solution. This was due to the importance of capital, production and land.

After the Second World War, new definitions of the term innovation began to appear. These definitions presented innovation as an invention with a specific purpose. To a wider extent, the definition of innovation referred to the whole process, i.e. a series of activities which led to the creation, development and introduction of new, for a specific enterprise, values in products or new connections of means and resources [8].

In the following years, innovation started to be perceived not from a technical, but from an economic point of view. The main author of this definition is $\mathrm{P}$. Drucker. He believed that "systematic innovation consists in a deliberate and organized search for change and a systematic analysis of the opportunities for social or economic innovation that such a change could enable" [3].

One of the most modern and also most frequently quoted definitions of innovation is the definition in the New Oxford Dictionary, which says that innovation is the implementation of something new.

A more developed definition of innovation was presented by D. O'Sullivan and L. in 2009. Dooley.
They defined the concept of innovation as the process of implementing large and small changes, radical and gradual, in products, processes and services that result in the growth of an organization's knowledge.

\subsection{Types of innovation}

Over the years, many classifications of the concept of innovation have been made. Classifications have been made on the basis of various criteria, however, the most common criterion for the division of innovations is the division by the type of activity to which they relate. In this division (Fig. 1), the following innovations can be distinguished: product, process, marketing and organizational [1].

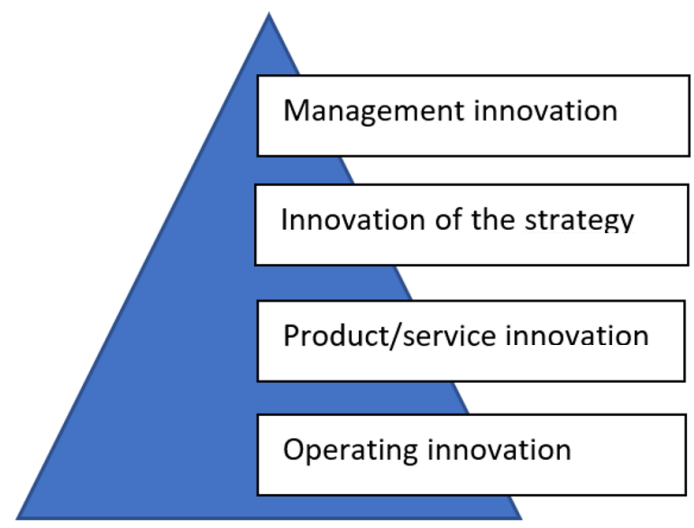

Fig. 1. The innovation pyramid [12]

Product innovation is an innovation involving the introduction of a new or upgraded product or service. This change must be a structural change or must be a technical and economic change of the product.

Process innovation is a process innovation that consists in developing a new or significantly changed manufacturing method, quality control, transport. A process innovation may consist in the introduction of changes in equipment or production organisation or may be a combination of both or result from the use of new knowledge. Innovations of this type may be related to the need to increase the efficiency of production or the way products are delivered.

A marketing innovation aims to implement a new marketing method, closely linked to changes in product design, distribution, promotion or pricing strategy. A marketing innovation is not related to changes in product or packaging design, the use of schematic marketing instruments aimed at conquering new markets.

Organisational innovation is a management innovation. It consists in introducing a new organizational method in the rules of operation adopted by the company, in the organization of the workplace or in relations with the environment. 


\section{INNOVATION IMPLEMENTATION STRATEGY}

The introduction of innovation is closely linked to carrying out analyses both inside and outside the company and then developing the project plan. Planning is the basis of the management process and the motto of those involved in management is: there is no action without planning. Therefore, one of the first stages of the innovation implementation process is to develop a strategy to implement a new solution [6].
The process map is a tool to present, among other things, successive operations or production stages. It allows for a simple presentation of relations between individual processs/stages.

The presented process map (Fig. 2) presents the procedure of implementation of innovative impregnated grinding wheels for grinding difficult to machine materials in the company Andre Abrasive Articles.
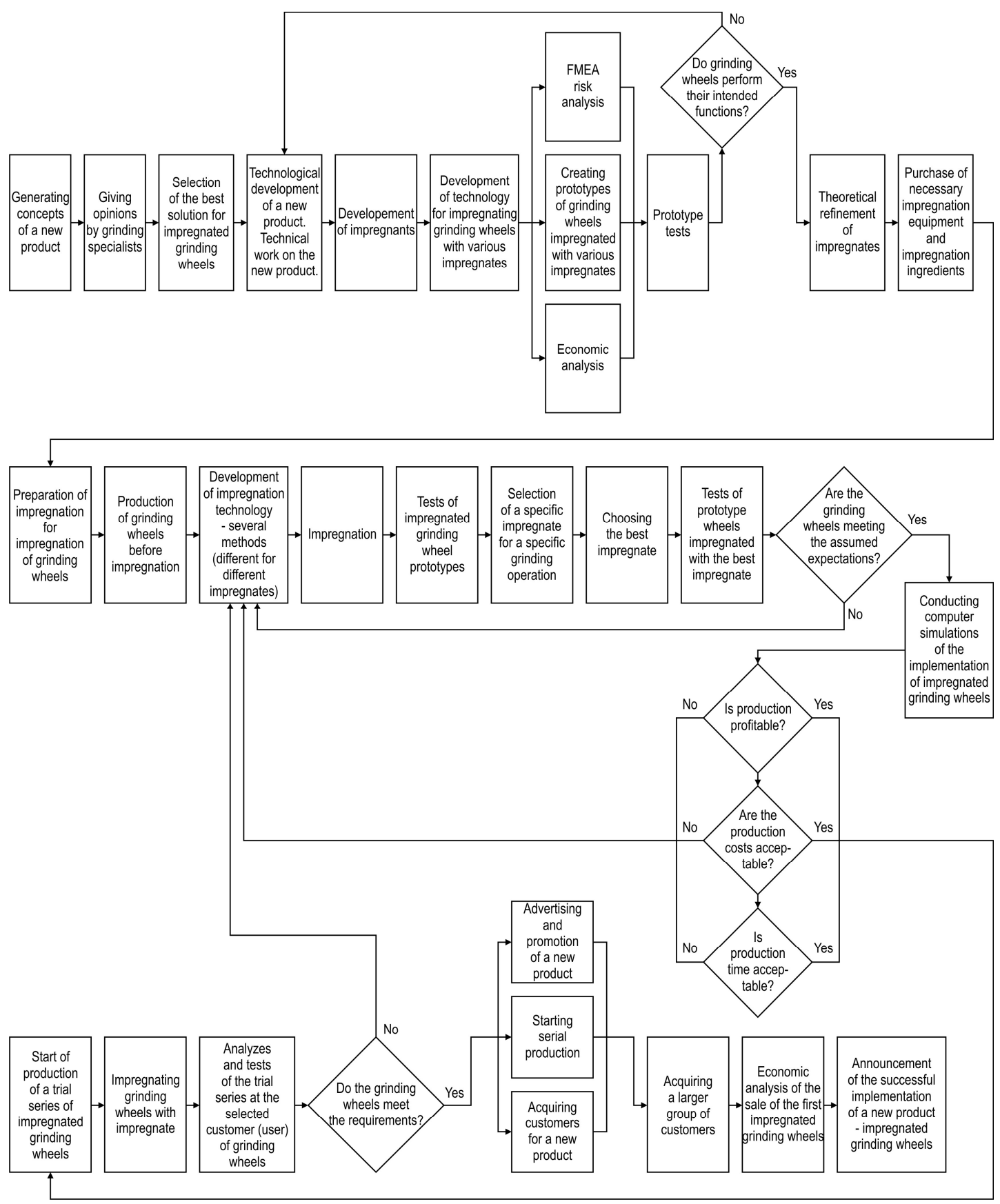

Fig. 2. Map of implementation of innovative impregnated grinding wheels 


\subsection{Economic analyses}

Economic analysis of the implementation process is an integral part of the development of innovations by enterprises. Making an economic analysis allows, to some extent, to predict the profitability of the process of introducing a new solution into production [7]. Figure 3 presents a diagram of areas of economic analysis in an enterprise.

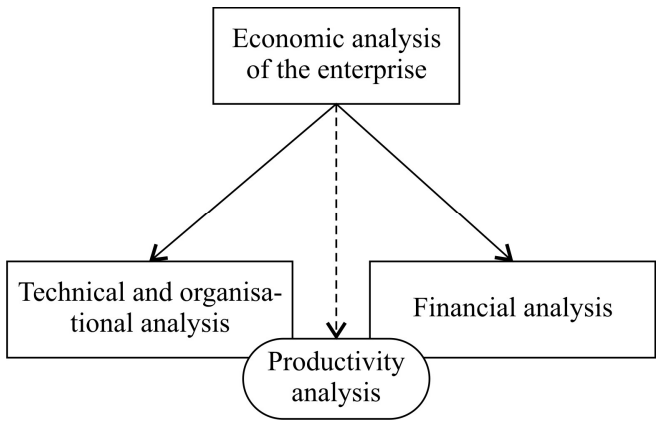

Fig. 3. Areas of economic analysis of enterprises [9]

The presented economic analysis was conducted for innovative

impregnated grinding wheels designed for grinding difficult to machine materials.

The economic analysis took into account the perspective of the market development and its longevity. Competitive products were also taken into account. The economic analysis was made on the basis of data from a survey conducted in Andre Abrasive Articles.

An analysis was carried out of the impact of abrasive tool impregnation on the cost of the final product, which is an abrasive tool.

The final cost of an abrasive tool depends on the cost of impregnation and the cost of the operation aimed at introducing the impregnant into the wheel's intergranular voids. Since Andre Abrasive Articles already has considerable experience in the field of vacuum impregnation of grinding wheels and has the necessary equipment to do so, an investment in the purchase of equipment is not necessary. The main costs associated with the impregnation of grinding wheels result from the purchase of raw materials for the preparation of impregnates containing sulphur, graphite, molybdenum disulphide or silicone.

Taking into account the costs of purchase of these raw materials as well as substances necessary to produce colloidal solutions, it has been calculated that the costs of finished grinding wheels, as a result of impregnation, will increase from $15 \%$ to $25 \%$. The difference will result from the type of impregnating substance used. On average, it can be assumed that the cost of finished wheels will increase by about $20 \%$ due to impregnation.

\subsection{Risk analysis of FMEA implementation}

Risk analysis of FMEA implementation allows to identify potential problems, failures that may occur in a given process and then to eliminate them. This method enables continuous improvement of the product or process by eliminating defects and making corrections.

The FMEA risk analysis carried out for Andre Abrasive Articles was aimed at investigating the risk resulting from the implementation of a technical and technological innovation, which is the implementation of innovative impregnated grinding wheels designed for grinding difficult to machine materials.

3.3. FMEA risk analysis of the implementation of innovative impregnated grinding wheels designed for grinding difficult to machine materials

This section presents a risk analysis of the implementation of innovative impregnated grinding wheels intended for grinding difficult to machine materials (Tab. 1). This analysis was performed for an abrasive tool manufacturer such as Andre Abrasive Articles from Koło, Wielkopolskie Province.

The manufacturer of abrasive tools accepts the risk index up to 150 . Therefore, in the table below (Tab. 1) the risk index values exceeding 150 are indicated in bold.

On the basis of the above FMEA analysis of the risk of implementing impregnated grinding wheels, it can be observed that the most probable cause of the risk is an incorrect selection of the type and also an inappropriate amount of impregnating substance. The risk index of improper selection or inappropriate amount of impregnant is 300 . This is the highest value of the overall risk index in the FMEA analysis of the method of modification of ceramic abrasive tools. The potential consequence of improper selection of the tool type or the wrong amount of impregnant can be damage to the grinding tool.

Another probable risk is the inhomogeneous filling of the grinding wheel with the impregnant as well as incorrectly selected technical characteristics of the tool and errors in the selection of parameters and machining conditions. Here the general risk index of non-homogeneous filling of a grinding wheel with impregnant is 192 . The potential threat of the above mentioned state of affairs is tool failure and the resulting danger for operators.

The next potential hazard, exceeding the value accepted by the manufacturer, equal to 150 , is too short a tool life. This may result from an incorrectly selected tool type or an incorrect amount of impregnant. This state of affairs contributes to faster tool wear, extended grinding operation time or increased costs of operations. 
Tab. 1. FMEA risk analysis of the implementation of innovative impregnated grinding wheels designed for grinding difficult to machine materials

\begin{tabular}{|c|c|c|c|c|c|c|c|}
\hline $\begin{array}{l}\text { Risk } \\
\text { no. }\end{array}$ & Potential risk & $\begin{array}{l}\text { Potential effects of the } \\
\text { risk }\end{array}$ & Potential causes & Relevance & Traceability & Probability & Risk \\
\hline 1. & $\begin{array}{l}\text { Tool with incorrect } \\
\text { cutting properties }\end{array}$ & $\begin{array}{l}\text { Damage to the grinding } \\
\text { tool. Lack or limited } \\
\text { possibility of obtaining } \\
\text { the assumed machining } \\
\text { results }\end{array}$ & $\begin{array}{l}\text { Incorrectly selected } \\
\text { tool type or quantity of } \\
\text { impregnating } \\
\text { substances used }\end{array}$ & 10 & 5 & 6 & 300 \\
\hline 2. & $\begin{array}{l}\text { Incorrect tool size in } \\
\text { relation to the } \\
\text { machining task }\end{array}$ & $\begin{array}{l}\text { Tool failure, } \\
\text { improperly processed } \\
\text { material, operator } \\
\text { injury }\end{array}$ & $\begin{array}{l}\text { Inappropriate selection } \\
\text { of the tool to the } \\
\text { requirements of the } \\
\text { machine tool and the } \\
\text { material to be } \\
\text { processed }\end{array}$ & 10 & 3 & 3 & 90 \\
\hline 3. & Tool life too short & $\begin{array}{l}\text { Faster tool wear, } \\
\text { extended grinding } \\
\text { operation time, } \\
\text { increased operating } \\
\text { costs }\end{array}$ & $\begin{array}{l}\text { Incorrectly selected } \\
\text { tool type or quantity of } \\
\text { impregnating } \\
\text { substances used }\end{array}$ & 8 & 5 & 4 & 160 \\
\hline 4. & $\begin{array}{l}\text { Difficulty in } \\
\text { purchasing the right } \\
\text { amount of tools in } \\
\text { relation to production } \\
\text { plans }\end{array}$ & $\begin{array}{l}\text { Disturbance of the } \\
\text { production programme, } \\
\text { extended time of the } \\
\text { task }\end{array}$ & $\begin{array}{l}\text { Complications in } \\
\text { obtaining impregnating } \\
\text { substances }\end{array}$ & 7 & 3 & 4 & 84 \\
\hline 5. & $\begin{array}{l}\text { Too difficult to } \\
\text { implement tools into } \\
\text { existing technology }\end{array}$ & $\begin{array}{l}\text { Production programme } \\
\text { disturbances }\end{array}$ & $\begin{array}{l}\text { Occurrence of } \\
\text { difficulties in } \\
\text { regenerating grinding } \\
\text { wheels }\end{array}$ & 3 & 4 & 4 & 48 \\
\hline 6. & $\begin{array}{l}\text { Need for specialised } \\
\text { training of grinding } \\
\text { tool operators }\end{array}$ & $\begin{array}{l}\text { Additional time for } \\
\text { employee training as } \\
\text { well as possible delays } \\
\text { in starting the grinding } \\
\text { process }\end{array}$ & $\begin{array}{l}\text { Difficulties in } \\
\text { regeneration of } \\
\text { impregnated grinding } \\
\text { wheels and selection of } \\
\text { machining parameters }\end{array}$ & 5 & 3 & 5 & 75 \\
\hline 7. & $\begin{array}{l}\text { Too high cost of tool } \\
\text { and technology } \\
\text { compared to the } \\
\text { current situation }\end{array}$ & $\begin{array}{l}\text { Increase in unit } \\
\text { production costs }\end{array}$ & $\begin{array}{l}\text { High cost of } \\
\text { impregnated tools }\end{array}$ & 5 & 4 & 7 & 140 \\
\hline 8. & $\begin{array}{l}\text { Concerns about the } \\
\text { application of } \\
\text { innovative technical } \\
\text { and technological } \\
\text { solutions }\end{array}$ & $\begin{array}{l}\text { The need to persuade } \\
\text { operators to innovate, } \\
\text { to demonstrate its } \\
\text { benefits }\end{array}$ & $\begin{array}{l}\text { Original contact with } \\
\text { such tools }\end{array}$ & 4 & 5 & 5 & 100 \\
\hline 9. & $\begin{array}{l}\text { Different processing } \\
\text { results than expected }\end{array}$ & $\begin{array}{l}\text { Inappropriate condition } \\
\text { of the surface treated in } \\
\text { particular with regard } \\
\text { to the surface layer }\end{array}$ & $\begin{array}{l}\text { Incorrectly selected } \\
\text { tool type or quantity of } \\
\text { impregnating } \\
\text { substances used, as } \\
\text { well as incorrect } \\
\text { selection of machining } \\
\text { parameters }\end{array}$ & 6 & 4 & 5 & 120 \\
\hline 10. & Danger to operators & Tool failure & $\begin{array}{l}\text { Heterogeneous filling } \\
\text { of the wheel with } \\
\text { impregnant, poorly } \\
\text { selected technical } \\
\text { characteristics of the } \\
\text { tool, improperly } \\
\text { selected machining } \\
\text { parameters and its } \\
\text { conditions }\end{array}$ & 6 & 8 & 4 & 192 \\
\hline
\end{tabular}


As it results from the above FMEA analysis of the implementation risk, the least probable problems with restoring the cutting capacity of impregnated grinding wheels (risk index equal to 48) are encountered. A threat resulting from the renewal of impregnated grinding wheels may be a disruption of the production programme, i.e. delays in production and execution of orders for impregnated grinding wheels. In order to prevent the above mentioned risks, it is necessary to constantly control the process of impregnation of the wheels. Inevitably, the quantity of impregnating substances used should be controlled, as this involves the highest values of risk indicators. It is also important to test the prototypes of impregnated wheels before they are put into production, which allows to minimize the risk of implementation.

\section{CONCLUSIONS}

The process of innovation implementation is an inevitable phenomenon in every developing enterprise. It results from the constant development of the world, increase of customers' knowledge and willingness to meet the needs generated by the production market. The following conclusions can be drawn from this article.

1. Implementation of novelties involves some risk, therefore it is necessary to prepare well for this process.

2. Before starting the implementation of innovative impregnated grinding wheels, economic analyses as well as risk analysis of FMEA implementation were conducted. This allowed to reduce the risk of failure to some extent.

3. Thanks to economic analyses, the company received an answer whether and to what extent the process of implementation of innovative grinding wheels is profitable, as well as what costs it involves for the company.

4. The analysis of the risk of FMEA implementation made it possible to assess which of the risks are most likely to occur and what risks are associated with it. Thanks to this, it is possible, already at the planning stage, to remove possible threats or their causes.

\section{References}

1. Brzeziński et al., 2001, Technical and organisational innovation management, Difin, Warsaw (in Polish)

2. Dagkinis I., Lilas T., Nikitakos N., 2011, Apply FMEA modeling to a floating ecological desalination unit, Journal of Polish Safety and Reliability Association, Vol. 2, No. 1, pp. 73-82.

3. Drucker Peter F., 1985, Innovation and Entrepreneurship Practice and Principles, Harper \& Row Publisher, New York

4. Florida R., Mellander C., King K.: The Global Creativity Index. Martin Prosperity Institute, Rotman School of Management. University of Toronto, Toronto 2015.
5. Knosala and others, 2014, Innovation Management, Polish Economic Publishers, Warsaw (in Polish)

6. Konsala R., 2017, Inżynieria Produkcji, kompendium wiedzy, Polskie Wydawnictwo Ekonomiczne SA, Warszawa

7. Kovtunenko Yu. V., Valyanskaya A. O., Miroshnykova K. O., (2017), Economic analysis and its importance in the management of the enterprise, Economy: real time, Nr. 1 (29), pp. 80-85.

8. Niedzielski P., Rychlik K., 2007, Innovation and Creativity, University of Szczecin Publishing House, Szczecin (in Polish)

9. Sierpińska, Jachna, 1995, Evaluation of a company according to world standards, PWN, Warsaw (in Polish)

10. Słowiński B, 2009, Logistics Process Management Engineering, Koszalin University of Technology Publishing House, Koszalin (in Polish)

11. Wiśniewska J, Swiadek A, 2005, Technological and social innovations in socio-economic development selected aspects, Naukowe Wydawnictwo IVG, Szczecin (in Polish)

12. http://z.nf.pl/galeria/org/15959.jpg

13. European Commission, European Innovation Scoreboard 2016, http://ec.europa.eu/DocsRoom/documents/17822.

\section{Biographical notes}

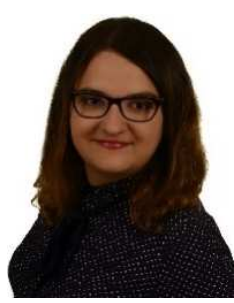

Emilia Gierszewska received her B.Sc. degree in Management and Production Engineering from the Faculty of Mechanical Engineering at the Koszalin University of Technology in 2016. Her scientific interests focus on problems concerning implementation of innovative processes and products, rapid prototyping and reverse engineering methods as well as abrasive machining processes. She has presented the results of her work in one international and three national conferences. She is an author and a co-author of 7 scientific papers in conference proceedings.

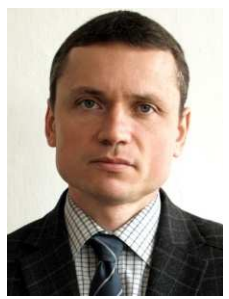

Krzysztof Nadolny received his M.Sc. degree in Mechanics and Machine Design and next the Ph.D (with honors) as well as D.Sc. degree in Machinery Construction and Operation from the Koszalin University of Technology, in 2001, 2006 and 2013, respectively. Since 2006, he has been a researcher in the Department of Production Engineering at the Koszalin University of Technology, where currently he works as an associated professor and the head of the research-didactic team for production planning and control. His scientific interests focus on problems concerning machining processes and tools, efficiency, monitoring and diagnostics of machining processes as well as tribology. He has participated in 2 international and 3 national research projects, presenting results of his work at 10 international and 21 national conferences, published more than 230 scientific papers in international and national journals, book chapters, as well as conference proceedings. He is also the author of 6 monographs and 13 national patents. 